【報文・論文】 口之津地すべりのすべり面形成過程について（II）

玉 田文吾*

On the Process of Formation of the Slide Planes at Kuchinotsu Landslide Area (II) by Bungo TAMADA

\section{3. 地すべり面の形成過程について}

テストピットによって検出されたすべり面が地層中に おいてどのような経過をたどって形成されるかについて は, 地すべりの発生原因にもつながるので重要な問題で ある。しかし多くの要因が重なり合っており，口之津地 区の地すべり面は最近になって突然形成されたものでは ないと思われる点も多く, 地質学的な時間要素も入って くるので解明は容易なことではないが，既述の観察結果 をもとに形成過程を検討してみたい。

\section{1 冨士山地区の地質構造}

1. 概 要

本地区は島原鉄道口之津駅の北約 $2 \mathrm{~km}$, 県道口之津 雲仙線の左側に位置している。地区のほぼ中央に標高 $173.7 \mathrm{~m}$ の冨土山があるが, 現在その南側に地すべりか゚ 発生している。この間の距離は山頂からの投影距離にし て $200 \mathrm{~m}$ にすぎない。富士山は図-13の推定断面図に示 すごとく, 現在は一種の Tholoid 型を呈する凝灰質集 塊岩 (agglomerate) および熔岩質集塊岩によって構成 されている。これらの岩石中には柱状節理に似た亀裂が 無数に発達しており, 岩質は多孔質熔岩を含むもので全 体的には空隙率が大きい（一般には口之津層火山䃯岩と もいわれる)。これらは数回の玄武岩活動の最上部にあ たる両輝石安山岩熔岩に由来する火山砕角物といわれて おり， 口之津層群よりやや新しい時代のものとされてい る4)。冨士山の周辺は既述の口之津層群が発達しており, 全体的にはしゅう曲性の構造で侵食地形であるが，地す ベり面が検出された地区だけを見ると，ほぼ東西の走向 と $17^{\circ}$ の傾斜をもつ単斜構造をしている。

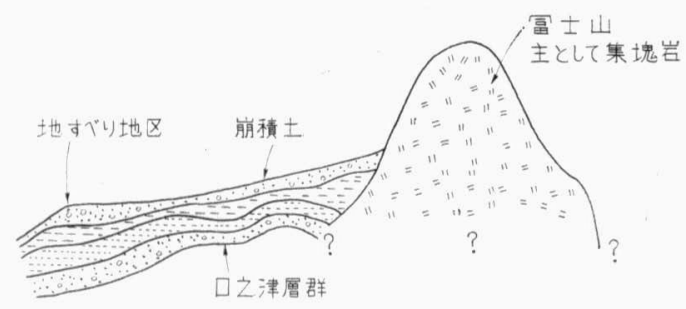

層厚などは全般的な傾向を示すために暲張表示してある

図-13 冨士山地区の断面図

・西日本工業大学土木工学科
2. 運積性既成粘土

すでに述べたように地すべり地区の最上部は薄い崩積 土によって被覆されており, 図-5 に模式断面図として この状態を表示した。このよらに基盤上に滞積した崩積 土は口之津地区に限らず各地に見いだすことができる。 ここでは冨土山地区における崩積土の特徴について述べ てみたい。

（1）崩積土中にはこの付近にある火山岩などの転石を 多く含んでいるが，これらが不規則に混入しているので はなく，層状になり，分級されて粒径，形状の揃った転 石層または転石帯を形成している(写真-8 参照)。また 転石層は水平に滞積しておらず，山地に流れこんた゚状態 を呈するために膨縮が大きいものになっている。これら の転石層（普通 $2 \sim 3$ 層）の間には檪を含む細粒土層が はさまれているが，透水係数 $10^{-6} \sim 10^{-7} \mathrm{~cm} / \mathrm{sec}$ の不透 水層である。崩積土全体の垂直方向の粒度と含水比とを 測定すると, いたる所, 陶汰分級されて滞積した跡と, 乱された跡とが残っている。

（2）分級がとくに良好な場合は図-14 の模式断面に示 したように薄い粘土層が形成されている。写真-9 は富 土山地区に隣接した大拔地すべり地区の崩積土の中に見 いだされた粘土層である。これらの層は有限のひろがり をもっており，膨縮が極端で不定な形状をなし，方向性 を有し, 流路性の滞積相をもつと同時に異方性がいちじ るしい。とくに重要なことは欠層が見られることで水 平, 垂直方向に不連続であることも特徴の一つである。 都いままで, このような崩積土中の粘土層は, 崩積土中

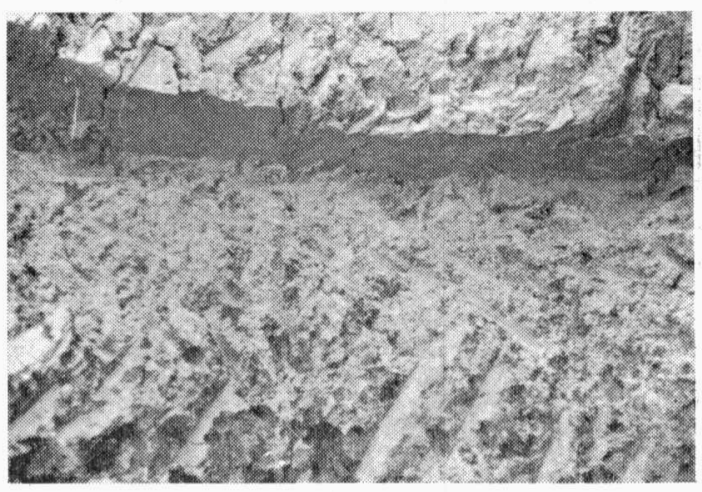

写真-9 口之津地域の崩積土中の粘土層（茶褐色の 带状層) 
地すべり Vol.8, No.1 (通卷 第25号)

の地下水のためにこれらが風化の結果生成するかのよう に思われてきたが，口之津地区ではこれらの粘土層が地 中に执いて岩石の風化によって直接生成したものではな いからこれらを“運積性既成粘土”といら。

（3）運積性既成粘土の傾斜は一般に小さく，水平に近 い状態を呈する。粘土層の層面が比較的はっきりしてい 尚場合には water film が存在するが，この成因につい てはすでに発表したことがある5”。その後の考察によっ て water film には成因, 水膜の厚さ, 面の平滑度によ って差違のあることが判明しているが，運積性既成粘土 層に見られるるのを“擦過性 water film”之呼称する。 この種の water film は主として崩積土中にだけ見られ るが，かなり制約された状態のるとで生成される ${ }^{6)}$

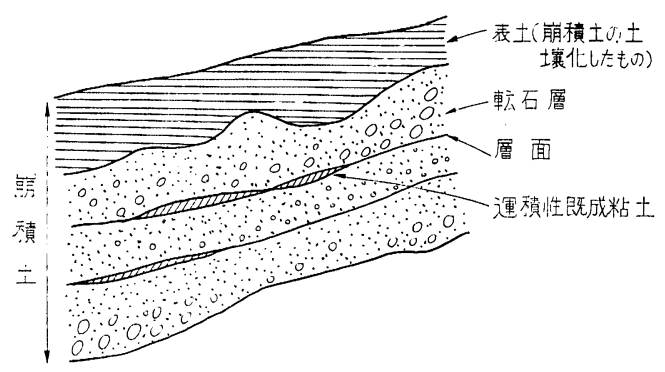

図-14 運積性既成粘土の賦存状況

（4）運積性既成粘土は長期間にわたる間に圧密が完了 しており，これのせん断強度定数は表-1 のようにかな り大きい。またこれらの先行圧密荷重は過圧密状態であ ることを示ずす。

一般に層面が漸移的であり，上下層との区別が判然と しない運積性既成粘土には water film 面も見られない。 このために運積性既成粘土をさかいにすべることは少な いが， water film 面があるとこの面を中心に滑動する 場合が多い。このような型の地すべりを“再発型地すべ り”と定義している。

3. 残積性既成粘土

テストピットにおいて，風化頁岩と摃乱带の界面付近 （すなわち崩積土と風化岩盤との界面付近, 写真-2 で はスタッフ 50〜 60 cm の位置) をくわしく観察すると 薄い（厚さ $0.2 \sim 0.5 \mathrm{~cm}$ ) の粘土層を見いだすことがで きる。この付近の地層を観察した結果を要約するとつぎ のようになる。

（1）風化頁岩の層面はかなり侵食されて和り, やや顕 著な山凸状を呈すると同時に酸化鉄のために橙褐色儿変 色している。図-15はこれらの状態を模式的に示した。

崩積土は風化頁岩の表面を削り, その一部を巻さこむ ようにして滞積している。薄層粘士は崩積土と風化頁岩 との層界面付近に見いだされる。

（2）頁岩が長時間大気に露出されたり，水浸されたり するとその表面は風化されて軟化する。このような時期
表-6 冨士山地区残積性既成粘土の $C_{c u}, \phi_{c u}$

\begin{tabular}{c|c|c|c|c}
\hline 採取深度 & $\begin{array}{c}\text { 単位体積重量 }\left(\mathrm{g} / \mathrm{cm}^{3}\right) \\
\text { 含水比 } \\
(\%)\end{array}$ & $\begin{array}{c}\text { 粘 着 力 } \\
\left(\mathrm{kg} / \mathrm{cm}^{2}\right)\end{array}$ & 内部摩擦角 \\
\hline $2.10 \mathrm{~m}$ & 1.708 & 42.22 & 0.20 & $23^{\circ} 40^{\prime}$ \\
\hline
\end{tabular}

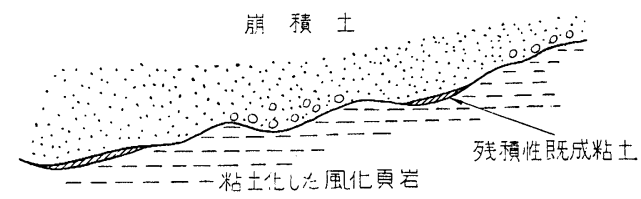

図-15 残積性既成粘土の模式図

に風化岩盤の表面に崩積土が流れてくると加水擦過され て，この部分に薄い粘土層ができる。これらの粘土層は 崩積土が滞積した後, 地下水によって岩石から粘土へ变 わったものではなく, また運積によって滞積生成したも のではないから，これらを“残積性既成粘土”という。

（3）これらの粘土の存在状態は図-15 のよらになって 扣り, 風化頁岩面表部に沿って部分的にでき, 連続した ものは見あたらない。また，きわめて薄いことも特徴で ある。急傾斜部には生成せず $10^{\circ}$ 内外の面を形成する。

不連続であることはもちろんであるが，膨縮は見られ ず一方に厚いクサビ状を呈して括り，薄い方から厚い方 へと擦過された条痕がある。粘土層に多数の小䃯を含ん でいることも一つの特色であるが，この種の既成粘土は 風化玄武岩と崩積土との層界面にも見いだされる。

（4）富士山地区に打秥残積性既成粘土の直接せん断 試験結果は 表-6 のようであり, 強度定数はかなり大き く,これらの数值を使用して安定を計算すると本地区で は一応安定を保つことになる。

従来, 崩積土之風化岩盤との層界面が粘土化してすべ るといわれてきたが，このような面には残積性既成粘土 が生成しやすいことにも起因がある。しかし，このよう な面がすべる場合，その大部分はつぎのような機構にな っている。

冨士山地区に打ける残積性既成粘土中には water film 面は検出できなかったが，運積性と同じく“擦過性 water film” が形成される可能性はある。この場合自然 条件が揃らと滑動を開始するが， water film 面が地下 水面下にあり，かつ地表面から浅い所にあれば，この面 が滑動することによって加水擋拌され，吸水膨張によっ て粘土層がだんだんと厚くなり, 本格的な地すべり粘土 に生長してくる。

このような既成粘土を仮りに “第一次地すべり粘土” と呼称するならば，これが一般に地すべり粘土といわれ ている“第二次地すべり粘土”に変化する可能性をそな えていることに既成粘土の重要性がある。

\section{2 冨士山地区の地すべり面形成過程}

1. 破壞性 water film 面の形成 
テストピット掘削の結果, 冨士山地区の地すべり面は 図-5 に示したように, 崩積土の下位にあるとくに風化 した頁岩中にあることが判明した。この位置をさきに述 ベた既成粘土との関係に执いて対比すると 表-7 のよう になる。ここで破壊性 water film 面というのは写真-2 に示した白線特よび 写真-6 に示したよらな光沢をもつ 平滑面である。このような面が，どのような機構によっ て形成されるかは重要な問題であるが, 現在までに判明 していることはつぎのような事項である。

(1) これらの面は磨いた大理石のように全く条痕がな く, 面にはわずかな粘土も付着していない。写真-7 に 示すごとく鋭利なナイフで切ったように分離する。これ らの面を人工的につくるためナイフで切っても条痕がで

表-7 富士山地区の地すべり面付近の構造

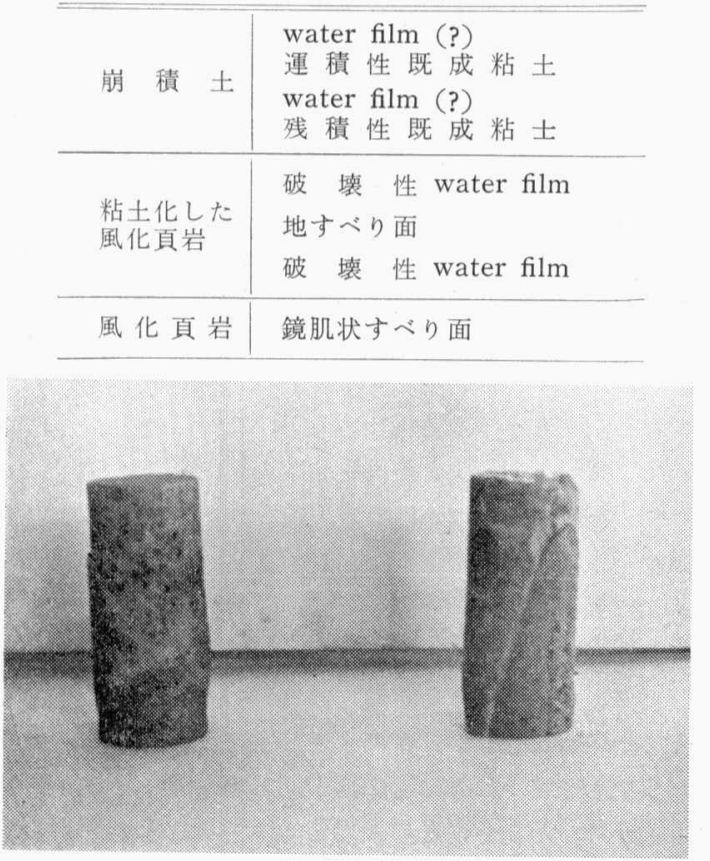

写真-10 冨士山地区の試料に生成した破壊性 water film 面

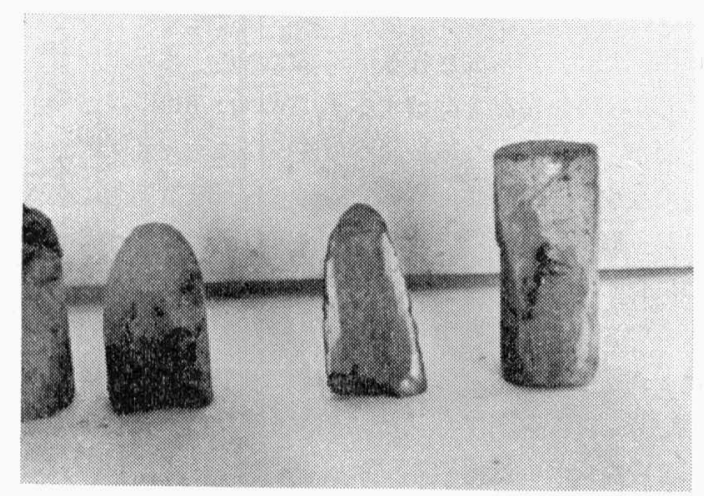

写真-11 冨士山地区の試料に生成した破壊性 water film 面 (写真-6の面と類似している)
きたり，乱れて光沢がなくなったりするために普通の状 態では実験室で再現することがむずかしいが，つぎの方 法によって現地のものとほとんど変化のない面を人工的 につくることが可能である。

崩積土および既成粘土では生成しないが，とくに風化 して粘土化した頁岩の非圧密非排水三軸圧縮試験におい て生成する。この場合, 試料は飽和して扣り, 封圧され た試料内部に発生する間隙水圧 $u$ と側圧 $\sigma_{3}$ との間には $u \geqq \sigma_{3}$ となることが必要である。

これ以外の試験方法打よび試料の状態では，一応破壊 面はできるが破壊面に粘土をはさむ条痕面が形成され る。

以上の方法で室内でっくった面および現地に見られる 面は, やや厚い水膜が形成されているのでこれを“破壊 性 water film”とい5。写真-10, 11 は室内でつくった 破壊性 water film 面である。

（2）冨士山地区に見られる破壊性 water film はつぎ のような過程によって形成されたものと思う。

同じような試料について非圧密非排水の状態で直接せ ん断試験を行なっても破壊性 water film は生成されな い。このよ5な事実から推定すると図-16(a)のように， 粘土化した風化岩盤が斜方分力によってある面から拘束 状態において強制破壊したるのでなく，図-16(b)のよう に横方向の圧力 $p_{h}$ によって生成した破壊面と思える。 この場合, 破壊性 water film 面生成の条件として

$$
\sigma_{3}=\gamma_{s} h \leqq u=\gamma_{w} h_{w} \cdots \cdots \cdots \cdot(1)
$$

が必要であるが，このよらな状態に置かれるのは，地表 面から深さ $h$ にあり， $\sigma_{3}=\gamma_{s} h\left(\gamma_{s}\right.$ は粘土化した風化 頁岩の飽和単位体積重量）なる土から゙り応力を受けてい る風化岩石上に水深 $h_{w}$ なる水が覆って $\gamma_{w} h_{w}\left(\gamma_{w}\right.$ は水 の単位体積重量）なる間隙水圧を発生している場合など が該当するが，この状態は後述するように粘土化した風 化岩盤がかなり制限された特殊な条件下になければなら ぬことを暗示している。

（3）この状態に置かれた粘土化した風化頁岩のせん断
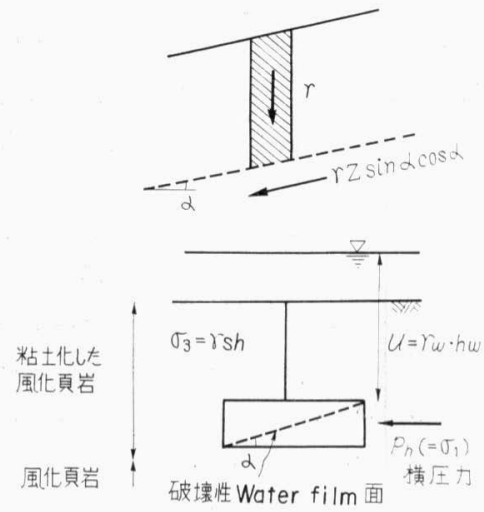

図-16 破壞性 water film 面の生成機構 


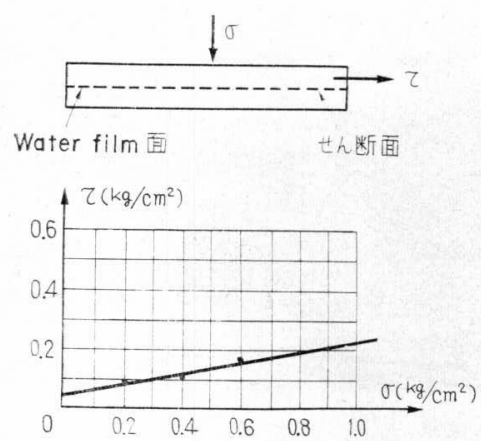

図-17 破壊性 water film 面の直接せん断試験 強度定数は

$$
\left.\begin{array}{c}
\tau_{f}=C_{u}=\frac{1}{2}\left(\sigma_{1}-\sigma_{3}\right)_{\max } \\
\phi_{u}=0
\end{array}\right\}
$$

となり，富土山地区の場合は 表-8 のようにわずかの横 圧力 $p_{h}\left(=\sigma_{1}\right)$ にて破壞し，破壊性 water film 面が生 成する。

\section{2. 鏡肌状すべり面の形成}

現在のすべり面の下位にある鏡肌状すべり面を含む風 化頁岩は 表-1 に示すように, かなりの力学的強度を保 持しているために，この内部にこのような破壊面ができ ることは，自重による斜方分力のみによって形成された とは思えない点がある。さきにも述べたように冨土山付 近は，かなりの地かく変動（しゅう曲作用なと゚）を受け た形跡があり，近在には玄武岩の貫入体なども見られ る。この場合, 滞積岩は一種の横圧力を受けるが, 頁岩 が風化によって軟化した時点においては, 横圧力によっ て図-16 と全く同じ機構により鏡肌状すべり面を発生す る8)

（1）横圧力による破壊は弾性的なるのでなく，時間的 要素をもって作用する横圧力のために塑性的な破壊なお こす。破壞面がさらに変位によって擦過されると写真-12 のように擦過条痕と薄い粘土が生成する。これらは岩石 の風化程度によってことなり, 風化が進行して含水比が 大きいほどはっきりした条痕と粘土ができる9。

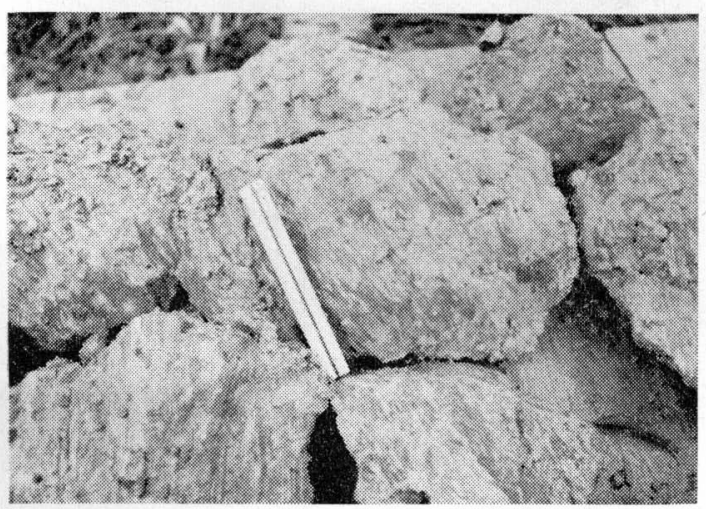

写真-12 富士山地区に見られる鏡肌状すべり面の条痕 之粘土
（2）このような鏡肌状すべり面は，口之津，北松地 すべり地区では例外なく見いだすことができる。このた めに鏡肌面の形状と相まって，これが地すべり面である ような印象を与えるが，これらの面は現在滑動して扣ら ず，地すべり現象とは直接に関係がないことも鏡肌の特 徵である。しかし，さきに述べたようにこれらの風化頁 岩の非圧密非排水三軸圧縮試験を行なうと, 鏡肌状破壊 面ができることからみて，この付近の風化岩層がなにか の形で横圧力を受けたことはほ涪間違いないことを示す ものである。

（3）鏡肌状すべり面と地すべりとの関連性は，口之津 地区では横圧力との関係になる。すなわら地表面から漸 移的に風化した頁岩が横方向の応力を受けて破壊し, 上 部には破壊性 water film，下部には鏡肌状すべり面を形 成し，これらが地中に残存していることに問題がある。

な招冨土山地区に扮ける鏡肌は, 地区全般にわたって 形成されているのではなく部分的に存在しており，地域 的な横圧力を受けた形跡がある。

3. 地すべり面の形成過程

すでに述べたように冨土山地区の地すべり面は，破壊 性 water film 面帯の中にあることが判明している。こ のようなすべり面がいかにして形成されたかを検討して みたい。

（1）地すべり面はその位置からみて，破壊性 water film 面と関係がある模様である。さきにも述べたよう に破壊性 water film 面は, わずかな横方向の応力によ って生成したもので，これらがそのままの状態で粘土化 した風化頁岩中に保存されていたものである。この付近 の粘土化した風化頁岩は崩積土の重量によって圧密され たが，表-8 に示したように過圧密粘土の特性を現わ す。破壊性 water film 面がちょうどせん断面になるよ

表-8 冨士山地区破壊性 water film 面付近風化頁岩の 物理, 力学的性質

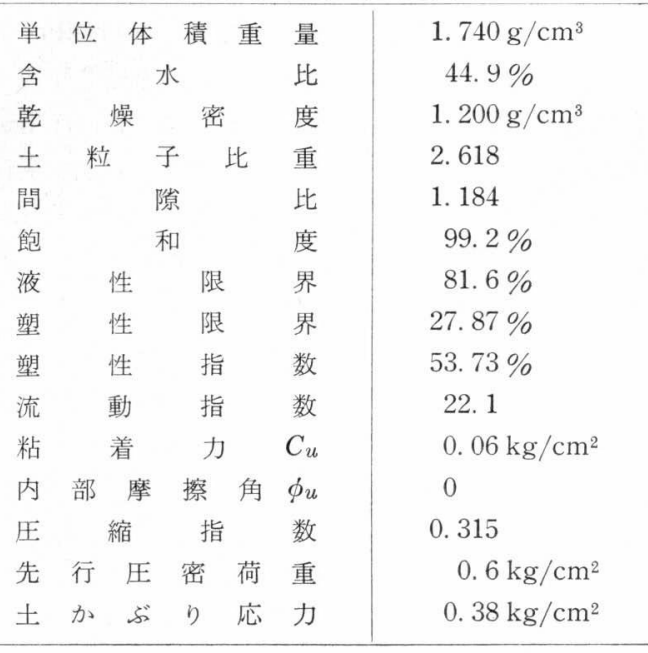




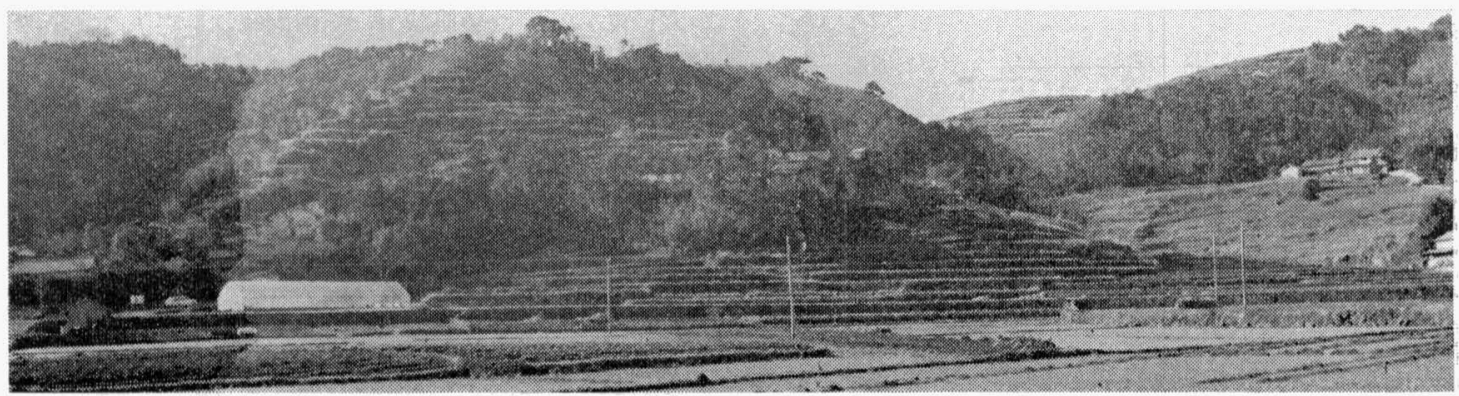

写真-13 万詰地すべり地区全景

表-9 破壊性 water film 面付近のせん断強度定数と地 すべり粘土の強度定数

種 類 $\left|\begin{array}{c}\text { 粘着力 } \\ \left(\mathrm{kg} / \mathrm{cm}^{2}\right)\end{array}\right|$ 内摩擦角 $\mid$ 試験 条件

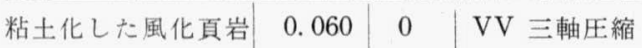
破壊性 water film $0.05911^{\circ} 05^{\prime} \mathrm{CV}$ 一面せん断 地すくり粘土 $0.215 \quad 9^{\circ} 00^{\prime} \mathrm{CV}$ 一面せん断

らに圧密非排水による一面せん断試験を行ならと视, 図-17 および表-9 の関係をらる。これからみても地中に 残存する water film 面が最弱面といらことになる。

（2）このような弱面はせん断抵抗がいちじるしく低い が，不連続であるためにただちに滑動するにはいたらな い。図-18の ab, cd, ef は破壞性 water film を示す。 bc, ed 部分が崩積土を含む自重による斜方分力, また は地かく変動に起因する徐々な横方向の応力によって集 中応力を受けて破壊すると, af なる一連のすべり面へ と転化する11。ここれが地すべり面形成の一過程である。

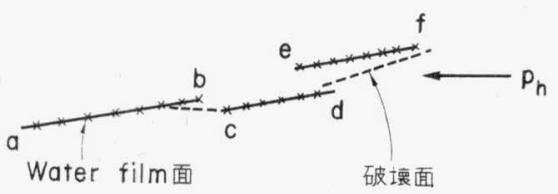

図-18 破壊性 water film 面のすべり面への転化機構

（3）このような機構によって破壊性 water film がす べり始めると, 擾乱作用と加水作用, 吸水膨張作用（富 土山地区の場合にはすべり面が浅いので，この作用が容 易に進行する）によってこの面が地すべり粘土に変わっ てくる。すなわち 写真 -6 の面が 写真 -4 に示す面へと転 化する。地すべり粘土ができると, すべり面のせん断抵 抗は破壊性 water film 面のそれと比較するとかなり大
きくなる。表-9 はこの状態を示したものである。

（4）地すべり粘土の生成にともなって，この付近のせ ん断抵抗が増加するということは, 従来の考え方とは違 らが, 地すべり発生機構は, 破壊性 water film 面とい う“一次地すべり面”が素因として既存し，これに誘因 が加わって地すべり粘土をともなう “二次地すべり面” に変化すると解釈すればよい。

岩石が風化することで地すべり粘土ができ，これが誘 因となって地すべりを誘発するのではなく，弱線があ りこれが動くことによって地すべり粘土ができるとい った考え方が，冨士山地区のすべり面の形成過程であ る。

\section{参考 文 献}

4）松本達郎：日本地方地質誌, 九州地力

5 ）玉田文吾：地すべり地区の斜面崩壊に打よぼす water film の影響について, 土木学会第 24 回年次 学術講演会講演集

6) 玉田文吾 : 長崎県北松地区に拈ける地すべり発生機 構の特性（その 3)，地すべり Vol 7, No 1 .

7 ）玉田文吾 : 岩層中の地すべり粘土と先行圧密荷重と の関係 土木学会第25回年次学術講演会講演集

8 ) 玉田文吾 : 岩層内に形成される地すべり面の発生機 構について, 第 3 回岩の力学国内シンポジゥム講演 集

9)，11）卞田文吾 : 第 3 回岩の力学国内シンポジウム講 演集

10）玉田文吾 : 地表面の移動速度から見た地すべり現象 と午の解析 第 4 回土質工学研究発表会 